ROCZNIKI PEDAGOGICZNE

Tom 11(47), numer $4-2019$

DOI: http://dx.doi.org/10.18290/rped.2019.11.4-3

\author{
EWA PASTERNIAK-KOBYŁECKA \\ MAŁGORZATA PRZYBYSZ-ZAREMBA
}

\title{
WARTOŚĆ RODZINY W OPINIACH STUDENTÓW PAŃSTWOWYCH UCZELNI WYŻSZYCH. ZARYS PROBLEMU
}

\begin{abstract}
WSTĘP
W XXI wieku dosyć powszechnie wskazuje się na kryzys rodziny, który jest spowodowany licznymi patologiami życia społecznego. Są również badacze, którzy w tym najważniejszym środowisku wychowawczym upatrują znaczny potencjał i niezliczone możliwości pozytywnego wpływu na rozwój jednostek. To rodzina przekazuje kolejnemu pokoleniu normy współżycia, tradycje, aspiracje kulturowe, jest poligonem doświadczalnym, na którym dziecko próbuje swoich możliwości i wchodzi w relacje z innymi. Tu są wpajane wychowankowi zasady i ideały. Córka (syn), naśladując mamę i tatę, uczy się miłości, szacunku i służby drugiemu człowiekowi. W Polsce i wielu krajach europejskich rodzina jest niezmiennie jedną z najbardziej cenionych wartości (Wolny, 2008, s. 251-266; Szafraniec, 2011, s. 41; Przybysz-Zaremba, Siedlaczek-Szwed, 2018, s. 903-910), obdarza miłością, opieką, tworzy warunki bezpiecznej egzystencji, kształtuje postawy prospołeczne. Stanowi dla młodego człowieka pierwszy model moralny, określając, co jest dobre, pożądane, a co złe. Zdaniem Władysława Majkowskiego (2008, s. 26) - rodzina, jako podstawowa grupa opiera się na potrójnym fundamencie: społecznym, biologicznym i duchowym. W obrębie tych fundamentów

Dr hab. Ewa PASTERniaK-KobyŁecKa, prof. UZ - Uniwersytet Zielonogórski, Wydział Pedagogiki, Psychologii i Socjologii, Instytut Pedagogiki; adres do korespondencji - e-mail: e.kobylecka@ipp.uz.zgora.pl; ORCID: https://orcid.org/0000-0002-8245-9012.

Dr hab. Malgorzata Przybysz-Zaremba, prof. PWSZ - Państwowa Wyższa Szkoła Zawodowa w Skierniewicach, Wydział Ekonomii i Administracji, Instytut Nauk Społecznych; adres do korespondencji - e-mail: malgorzata.pz@interia.pl
\end{abstract}


kształtuje się jej rozwój, współpraca pomiędzy członkami rodziny, wyznaczane są cele i wartości, które przekazywane są następnemu pokoleniu. Przyjęto definicję wartości, która wskazuje, że: ,są one tym, co jest dla człowieka cenne, godne pożądania, [...] co nadaje sens ludzkiemu istnieniu, wzbogaca życie jednostki, określając jej cele" (Kobyłecka, 2009, s. 29), czego pragnie bronić.

Pozytywne wspomnienia z lat dzieciństwa, świadomość skąd się pochodzi, pomagają kształtować poczucie tożsamości osobowej człowieka oraz pozwalają zachować mu zdrowie psychiczne. Wsparcie członków rodziny jest potrzebne w trudnych sytuacjach, chwilach smutku. $Z$ bliskimi można się również dzielić radościami i sukcesami. Na ogół silne więzi z rodzicami i rodzeństwem są zachowane na całe życie.

Młodzi dorośli najczęściej utrzymują kontakt z bliskimi niezależnie, czy studiują w miejscu zamieszkania (średnie lub duże miasto), czy poza nim (małe miasto, wieś). Relacje z rodziną są dla nich niezmiernie ważne. Badania przeprowadzone wśród młodych ludzi w latach siedemdziesiątych i osiemdziesiątych potwierdzają to w pełni. Najważniejszymi wówczas wartościami dla respondentów było: życie rodzinne, bliskie relacje z innymi ludźmi, przyjaciele (ponad 90\% badanych wskazywało na te wartości) (Zielińska, 1995). W latach dziewięćdziesiątych obserwuje się zmiany w zakresie najważniejszych wartości uznawanych przez młode osoby. Z badań przywoływanych przez Annę Zielińską wynika, że ponad $70 \%$ starszej młodzieży jako najważniejsze wartości wskazało posiadanie „przyjaciół” oraz „wykształcenia i rozległej wiedzy”, co będzie przydatne w dorosłym życiu. Obok tych wartości wysoko w hierarchii zostały usytuowane: „działania dla dobra innych” (71\%)”, „wolność, możliwość swobodnego decydowania o swoim życiu (69\%)". Badani uważali, że tego rodzaju wartości dają możliwość prowadzenia urozmaiconego i pełnego wrażeń życia, które jest bardzo atrakcyjne. Nisko sytuowano wartość rodziny i wychowania dzieci (zaledwie $26 \%$ wskazań) (Zielińska, 1995). Również z badań przeprowadzonych pod kierunkiem Eugenii Malewskiej (2008, s. 150) wynika, że rodzina została zepchnięta na dalszy plan. Badani wskazywali, że „[...] praca jest możliwością realizacji zawodowych aspiracji, jest wartością życiową [...]. Nie jest traktowana instrumentalnie, ale jest wartością, etyką pracy, która daje poczucie prestiżu, sens życia, możliwość kontaktów międzyludzkich. Ma wpływ na rozwój człowieka, poszerzanie jego wiedzy i doskonalenie osobowości" (Malewska, 2008, s. 150).

Niska pozycja rodziny w systemie wartości młodego człowieka mogła wynikać z przemian społeczno-gospodarczych związanych z rynkiem pracy, jakie zachodziły w latach dziewięćdziesiątych i w początkach 2000 roku. Duże bez- 
robocie w grupach zawodowych o niskim wykształceniu i kwalifikacjach, a także wzrost popytu na wysoko wykwalifikowanych specjalistów (informatyków, prawników, ekonomistów) (Zielińska, 1995) stały się istotnym czynnikiem wpływającym na system wartości młodych dorosłych również nieco później. $Z$ badań przeprowadzonych przez CBOS (2007) wynika, że „głównym celem życia młodych Polaków jest praca. Wysoka stopa bezrobocia w tym okresie doprowadziła do sytuacji, w której ponad 50\% młodych ludzi w wieku 18-24 lat traktuje pracę, jako najważniejszą wartość" (cyt. za: Przybysz-Zaremba, 2011, s. 263).

Dokonując przeglądu aktualnych badań dotyczących opinii studentów na temat priorytetowych wartości $\mathrm{w}$ ich życiu, zauważyć można, że rodzina ponownie znajduje się w czołówce. Na przykład z analiz przeprowadzonych przez Ryszarda Kałużnego i Łukasza Kałużnego (2014, s. 175-189) wynika, że rodzina (średnia 4,76) i zdrowie (średnia 4,89) to najwyżej cenione przez studentów wartości życia społecznego - niezależnie od płci, wieku, miejsca zamieszkania, czy sytuacji materialnej. Także badania ${ }^{2}$ Małgorzaty Kitlińskiej-Król (2016, s. 153-174) wskazują, że bardzo ważnymi wartościami dla studentów są: rodzina (80 wskazań), życie (71 wskazań) oraz miłość (68 wskazań). Podobnych wyników dostarczają badania ${ }^{3}$ przeprowadzone przez Tomasza Strózika (2014, s. 5-23) wśród młodzieży akademickiej stanu wolnego studiującej systemem stacjonarnym. Wynika z nich, że rodzina, obok zdrowia i przyjaciół, jest jedną z głównych wartości w tej grupie osób. Zbieżnych wyników na temat opinii studentów w zakresie preferencji uznawanych przez nich priorytetowych wartości, ze szczególnym uwzględnieniem rodziny, dostarczają również badania innych autorów (m.in. Czakon-Tralski, Borecka, 2018, s. 131-142; Więckiewicz, 2016, s. 112-128; Kawczyńska-Butrym, 2012, s. 277-296; Przybysz-Zaremba, 2011a, s. 73-81).

\footnotetext{
${ }^{1}$ Badania przeprowadzono w okresie: październik 2012 r. - czerwiec 2013 r. wśród studentów drugiego roku studiów licencjackich niestacjonarnych we wrocławskich uczelniach publicznych i niepublicznych. Średni wiek badanych to 25,5 lat. Badaniem objęto 178 studentów. Odpowiedzi identyfikowały wartości życia społecznego i oceniane były przez respondentów w skali od 0 do 5 pkt. W analizie danych empirycznych posłużono się średnią arytmetyczną, odchyleniem standardowym oraz wskaźnikami istotności różnic między dwiema średnimi dla prób niezależnych (por. Kałużny, Kałużny, 2014, s. 175-189).

${ }^{2}$ Badania przeprowadzono w 2014 r. wśród 120 studentów dwu niepublicznych uczelni wyższych na Górnym Śląsku. Badani to osoby studiujące na kierunku pedagogika, na poziomie studiów licencjackich w formie niestacjonarnej. Celem badań było poznanie opinii studentów na temat wpływu procesów globalizacyjnych na wartości przez nich preferowane (por. Kitlińska-Król, 2016, s. 153-174).

${ }^{3}$ Badania przeprowadzono wśród 1455 studentów studiów stacjonarnych dwunastu uczelni miasta Poznania (por. Strózik, 2014, s. 5-23).
} 
Przeobrażenia społeczno-gospodarcze i dokonujące się transformacje w znacznym stopniu zaburzyły system wartości młodych dorosłych Polaków. W prezentowanym tekście zostaną ukazane opinie studentów państwowych uczelni wyższych na temat wartości rodziny, która na przestrzeni ostatnich kilkudziesięciu lat rozmaicie była klasyfikowana.

\section{ZAŁOŻENIA BADAWCZE}

Celem podjętych badań, które miały charakter pilotażowy, było ustalenie (na podstawie analizy swobodnych wypowiedzi pisemnych), czy rodzina jest dla studentów ważną wartością. Poszukiwano odpowiedzi na pytania: „Jakie sq opinie studentów na temat wartości rodziny?"; ,Czym dla nich jest rodzina?”; „,Jaki model rodziny dominuje w wypowiedziach młodych ludzi?”; „Co studenci sa gotowi zrobić dla własnej rodziny?".

Badania zostały przeprowadzone w listopadzie 2018 roku w czterech państwowych uczelniach wyższych, znajdujących się w różnych rejonach kraju (UAM w Poznaniu, Uniwersytecie Zielonogórskim, Uniwersytecie Kardynała Stefana Wyszyńskiego w Warszawie oraz Państwowej Wyższej Szkole Zawodowej w Skierniewicach). Chętni studenci kierunków: pedagogika specjalna, filologia angielska, historia, filologia germańska, pedagogika (specjalność: edukacja przedszkolna i wczesnoszkolna, pedagogika opiekuńczo-wychowawcza, resocjalizacja z profilaktyką społeczną) zostali poproszeni o pisemne przygotowanie wypowiedzi na temat: Rodzina jako wartość, ze szczególnym uwzględnieniem czterech nakreślonych powyżej pytań badawczych. Łącznie w badaniu wzięło udział 80 studentów (po 20 osób z każdego ośrodka) w wieku od 19 do 25 lat. Większość stanowiły kobiety.

\section{OPINIE STUDENTÓW NA TEMAT RODZINY}

Na podstawie uzyskanego materiału można stwierdzić, że rodzina jest dla studentów bardzo ważną wartością, której pragną bronić, często za wszelką cenę. Opinie na temat tego środowiska wychowawczego są jednoznacznie pozytywne. Młodzi ludzie czują się wśród najbliższych dobrze i chcą w przyszłości również stworzyć kochającą się rodzinę, w której przejmą rolę matki/ojca. Oto kilka typowych wypowiedzi na temat tego, czym jest rodzina dla osób objętych badaniem: 
„Gdybym miał przedstawić najważniejsze wartości w moim życiu, to rodzina znalazłaby się na najwyższym stopniu piramidy. [...] Rodzina jest dla mnie wszystkim" (mężczyzna, 19 lat, filologia germańska, UZ);

„Rodzina to więzy krwi, emocje pozytywne i negatywne. To miłość, radość, wsparcie, współczucie, ale też rozpacz, gniew oraz zawiść. Rodzina jest jednością, zawsze i wszędzie mimo odległości i sporów. [...] Rodzina to przykład dla młodego pokolenia. To tradycje, wspólne obiady, wyjścia na spacer, wspólne święta i wakacje, wypady do kina i na zakupy" (kobieta, 20 lat, pedagogika specjalna, UZ);

„Według mnie rodzina to najważniejsza wartość w życiu. To bliscy ludzie, którzy zawsze są przy tobie i cię wspierają, gdy masz jakieś problemy. Możesz na nich liczyć, wasze relacje są oparte na życzliwości, szacunku i miłości. To najbliższe osoby w twoim życiu" (kobieta, 21 lat, wychowanie przedszkolne i nauczanie początkowe, UAM).

„Rodzina to atmosfera, która jest tworzona, to zaufanie do siebie, to przede wszystkim silne więzi między jej członkami [...]" (kobieta, 20 lat, pedagogika opiekuńczo-wychowawcza, UKSW).

„Rodzina to siła, jedność, zaufanie, szczęście” (kobieta, 21 lat, resocjalizacja z profilaktyką społeczną, PWSZ).

Wśród analizowanych wypowiedzi na temat rodziny nie ma żadnej, która miałaby jednoznacznie krytyczny charakter. Studenci w rodzinie szukają akceptacji, zrozumienia, bliskości, wsparcia. Chcą utrzymać dobre relacje z rodzicami, rodzeństwem, dziadkami, spędzać wspólnie czas. W wypowiedziach dominują aprobata i pozytywne emocje:

„Rodzina jest dla mnie najważniejszą wartością. To dzięki swoim rodzicom jestem tu i mogę np. teraz studiować. Bo w życiu właśnie o to chodzi, aby kochać, wydawać na świat potomstwo, wychowywać je i kochać jeszcze mocniej. Jest to niesamowicie piękny, wzruszający proces" (kobieta, 19 lat, filologia germańska, UZ).

„[...] rodzina to wsparcie, ciepło, bezpieczeństwo, miłość” (kobieta, lat 20, resocjalizacja z profilaktyką społeczną, PWSZ).

„[...] to pomoc na wszystkie możliwe sposoby. Rodzina to grupa ludzi, która dla siebie jest najważniejsza na świecie" (kobieta, 21 lat, pedagogika opiekuńczo-wychowawcza, UKSW).

Najprawdopodobniej osoby, które mają pejoratywne lub ambiwalentne nastawienie do tego środowiska po prostu nie podjęly się pisania wypracowania (miało ono charakter dobrowolny). 


\section{PREFEROWANY MODEL RODZINY}

Studenci głównie pisali o swoich obecnych rodzinach, które najczęściej są dwupokoleniowe, pełne. W niektórych brakuje taty lub mamy, kilka razy pojawia się ojczym. Członkowie rodziny prowadzą wspólne gospodarstwo domowe, wychowują potomstwo. W przypadku rozwodu rodziców dziećmi zajmuje się matka. Relacje między domownikami są zazwyczaj bardzo dobre („Moja rodzina to kochająca się grupa ludzi, którzy zapewniają sobie bezpieczeństwo, miłość i akceptację. Nie zawsze się rozumiemy, ale szanujemy siebie i własne wybory" kobieta, 21 lat, wychowanie przedszkolne i nauczanie początkowe, UAM; „Moja najbliższa rodzina to mama, tata, mój brat oraz moja najbliższa przyjaciółka. Moja sytuacja rodzinna jest ciężka, ponieważ tato pracuje za granicą i nie widzę go tak często, jak bym tego chciał. Gdy wszyscy są w domu, wtedy czas mógłby się zatrzymać. Moją przyjaciółkę traktuję niemalże jak siostrę. Wszyscy razem są nieodłącznymi częściami mojego życia" - mężczyzna, 19 lat, pedagogika specjalna, UZ).

Kilka wypowiedzi było dłuższych (3-4 strony). Opisywano w nich ze szczegółami trzypokoleniowe rodziny: ,[...] Moja rodzina jest ogromna, mnóstwo ciotek i wujków, którzy rzucają drobne w kieszeń lub krytykują styl bycia reszty. Mam wielu kuzynów i kuzynek, inaczej najlepszych przyjaciół z dzieciństwa. Zawsze wspólna zabawa tak nas pochłaniała, że traciliśmy rachubę czasu. Moja rodzina jest zgrana, kochająca się i bardzo troskliwa. [...] Oprócz nadzwyczajnych dziedziczonych cech mamy też we krwi «duszę imprezowicza». Tak, dokładnie. Uwielbiamy organizować imprezy. Prawie każda niedziela jest okazją do świętowania. Urodziny Babci, Dziadka, Mamy, Taty i tak przez cały rok (imieniny też wyprawiamy). Każda impreza to okazja na wspólne spotkanie i rozmowę. Wszyscy mówią, co u nich nowego, gdzie jadą na wakacje i co ich dzieci osiągnęły. Moja rodzina nie jest idealna ani niesamowita. Jest zwyczajna i za to ją kocham. Bywają kłótnie. Jednak mimo to zawsze wracamy do dobrych relacji. [...] Kocham swoją rodzinę i szanuję, bo to najlepsze, co mi życie dało." (kobieta, 20 lat, pedagogika specjalna, UZ).

Część osób stworzyło wizję rodziny, którą chcą założyć w przyszłości („Chciałabym, aby moja przyszła rodzina była pełna, tzn. składała się z obojga rodziców i dwójki dzieci [...], aby się wszyscy szanowali, wspierali i przede wszystkim kochali najbardziej na świecie, potrafili ze sobą rozmawiać" - kobieta, 19 lat, filologia germańska, UZ; „Chciałabym, aby moja rodzina była szczęśliwa, składała się z trzech osób (jedno dziecko), niekoniecznie bogata, ale spełniona, 
radosna, odnajdująca $\mathrm{w}$ sobie wsparcie" - kobieta, 20 lat, resocjalizacja z profilaktyką społeczną, PWSZ; „Chciałbym, aby moja rodzina była czteroosobowa, aby niczego nikomu w niej nie brakowało, aby czuć w niej było ciepło domowego ogniska, pozytywną atmosferę, by zawsze panowała w niej miłość, szacunek i zaufanie do drugiej osoby" - mężczyzna, lat 23, pedagogika opiekuńczo-wychowawcza, UKSW).

Rzadziej młodzi dorośli pisali ogólnie o rodzinie, uwzględniając jej różne cechy:

„Według mnie rodziną można nazwać zarówno rodzinę pełną, jak i niepełną, ponieważ przede wszystkim ważne jest to, aby jej członkowie okazywali sobie wzajemnie miłość, wsparcie, akceptację oraz szacunek" (kobieta, 20 lat, filologia angielska, UZ).

Ważnym elementem preferowanego przez studentów modelu rodziny jest związek małżeński, kobiety i mężczyzny, którego celem jest poczęcie i wychowywanie dzieci. Niektórzy badani tę kwestię relacjonowali w sposób następujący: „Rodzina to związek kobiety i mężczyzny, który scementowany jest dziećmi” kobieta, lat 20, resocjalizacja z profilaktyką społeczną, PWSZ; „To dwójka dzieci i mądry mąż. My, jako rodzice wykształceni, dajemy przykład dzieciom" kobieta, lat 21, resocjalizacja z profilaktyką społeczną, PWSZ; „Rodzina to oczywiście: mama, tata, dzieci, relacje, które są ciepłe, jest wsparcie, gdzie każdy spór można wyjaśnić, rozstrzygnąć bez agresji; to spędzanie czasu razem" kobieta, lat 20, resocjalizacja z profilaktyką społeczną, PWSZ. Dwie studentki z Państwowej Wyższej Szkoły Zawodowej dość mocno akcentują brak tolerancji wobec rodziny opartej na związku partnerskim i homoseksualizmie.

W niektórych wypowiedziach odnajdziemy wyrazy szacunku dla autorytetu rodziców. Wskazywane są pozytywne cechy matki (życzliwość, serdeczność, zaradność, mądrość, cierpliwość, dobroć) i ojca (inteligencja, poczucie humoru, opiekuńczość). Autorytet posiadają osoby reprezentujące taką wiedzę, umiejętności, postawy i doświadczenie życiowe, które pomagają $\mathrm{w}$ rozwiązywaniu problemów innym, potrafią interpretować rzeczywistość społeczną. Najczęściej niekwestionowanym autorytetem w rodzinie jest mama („Największym wzorem jest dla mnie moja mama, która nie jest tyko «mamą», jest wspaniałą córką dla moich dziadków, cudownym pedagogiem, niesamowicie ambitną osobą, silną, niezwykle empatyczną kobietą. Bardzo wiele mnie nauczyła" (kobieta 19, lat, filologia germańska, UZ).

Preferowany przez studentów model rodziny uwzględnia poczęcie i wychowywanie dzieci („Wartością nadrzędną każdego człowieka są dzieci, są tym na co czekam, są najwspanialszym darem - dla nich będę żyć" - kobieta, lat 20, 
resocjalizacja z profilaktyką społeczną, PWSZ). Większość z badanych w konstruowanym modelu własnej rodziny wskazywało na liczbę potomstwa, które chciałoby posiadać i wychowywać (tabela).

Tabela 1 . Model rodziny uwzględniający liczbę wychowywanych dzieci

\begin{tabular}{|c|c|}
\hline $\begin{array}{c}\text { Model rodziny uwzględniający liczbę dzieci } \\
\text { w rodzinie }\end{array}$ & Ogółem wskazań \\
\hline $2+1$ & 18 \\
\hline $2+2$ & 22 \\
\hline $2+3$ & 8 \\
\hline $2+4$ i więcej & 5 \\
\hline Razem & 53 \\
\hline
\end{tabular}

*Źródło: opracowanie własne.

W modelu rodziny $2+4$ i więcej, dwie studentki deklarowały chęć posiadania trójki własnych dzieci oraz dodatkowo pragnęły podjąć się adopcji. Najmłodsze osoby, objęte badaniami (dziewiętnastolatki), rzadko podawały liczbę dzieci w swojej przyszłej rodzinie.

\section{CO MŁODZI LUDZIE SĄ GOTOWI POŚWIĘCIĆ DLA RODZINY?}

Studenci przede wszystkim czują dla swoich bliskich wdzięczność i miłość, martwią się o nich. Pragną szczęścia dla członków rodziny. W większości są gotowi poświęcić swoje zdrowie (np. ofiarować organ do przeszczepu), studia, pracę, czas, oddać wszystko, co posiadają, by pomóc członkom swojej rodziny:

„Moja rodzina bardzo dużo poświęciła, żeby mnie wychować. Związane to było z licznymi wyrzeczeniami. Dlatego jestem w stanie poświęcić własne dobro i przyjemności, abym mógł się odwdzięczyć za wzorowe wychowanie" (mężczyzna, 19 lat, filologia germańska, UZ);

„Jestem gotowa oddać wszystko, co mam, tylko żeby członkowie mojej rodziny byli zdrowi i szczęśliwi” (kobieta, 19 lat, filologia polska, UZ);

„Jestem w stanie poświęcić karierę, pracę na rzecz opieki i wychowywania dzieci - one są dla mnie przyszłością" (kobieta, lat 20, resocjalizacja z profilaktyką społeczną, PWSZ); 
„Dla rodziny zrobiłabym wszystko, wszystko co zgodne z moimi zasadami i wartościami moralnymi i religijnymi, [...] mogłabym nawet oddać własne serce, żeby tylko uratować najbliższą mi osobę" - kobieta, lat 20, pedagogika opiekuńczo-wychowawcza, UKSW);

„Dla swojej rodziny jestem w stanie poświęcić wiele, spowodowane jest to bezgraniczną miłością, którą okazują mi rodzice i rodzeństwo. Byłabym gotowa poświęcić własne życie i szczęście” (kobieta, 20 lat, filologia angielska, UZ);

„Dla rodziny zrobiłabym wszystko, co byłoby potrzebne, co byłabym w stanie zrobić. Chciałabym im zapewnić spokojne i szczęśliwe życie, bez zbędnych kłótni i konfliktów" (kobieta, lat 20, pedagogika opiekuńczo-wychowawcza, UKSW);

„Dla swojej przyszłej rodziny zrobiłabym wszystko. Dosłownie. Mogłabym rzucić naukę, poświęcić karierę, cokolwiek, gdyby zaszła taka potrzeba. Dla aktualnej - to, co naprawdę muszę. Nic więcej” (kobieta, 20 lat, wychowanie przedszkolne i nauczanie początkowe, UAM).

\section{WNIOSKI KOŃCOWE}

Dla osób objętych badaniami rodzina stanowi fundamentalną wartość, która pomimo upływu czasu i doświadczania wielu niekorzystnych oddziaływań nie ulega dysfunkcji, a wręcz nabiera wyjątkowego znaczenia. $Z$ wypowiedzi studentów wynika, że:

a) rodzina stanowi dla nich wartość „ponadczasową”, która nadaje sens ich życiu;

b) rodzina jest: miłością, radością, wsparciem, wzajemnym współczuciem, więzami krwi, tradycją, wspólnym spotkaniem, relacjami, atmosferą, szacunkiem i zaufaniem do siebie, a także siłą, jednością, szczęściem, bezpiecznym azylem;

c) pragną założyć własną rodzinę, opartą na związku małżeńskim, scementowanym narodzinami dzieci i ich wychowywaniem; wartości materialne („bogactwo") są mniej ważne;

d) dla swojego potomstwa chcą być autorytetem, którego sami doświadczyli w wychowaniu ze strony własnych rodziców („mam szacunek dla autorytetu rodziców");

e) bezgraniczna miłość i wsparcie, jakie otrzymują ze strony bliskich powodują, że dla rodziny są w stanie poświęcić „wszystko" - własne dobro, przyjemności, studia, pracę, czas, zdrowie, a nawet życie („,mogłabym nawet oddać własne serce, żeby tylko uratować najbliższą mi osobę"). 
Zatem rodzina jest dla dużej grupy młodych dorosłych wartością najważniejszą, której nie są w stanie zastąpić niczym innym. Jest prymarną instytucją wychowania, pierwszym źródłem przekazu symbolicznego (Milerski \& Śliwerski (red.), 2000, s. 192); najbliższym człowiekowi środowiskiem życia (edukacji i rozwoju). Podjęty problem wart jest dalszych szerszych i bardziej wnikliwych badań.

\section{BIBLIOGRAFIA}

CZAKon-Tralski, D. Borecka, W. (2018). To co w życiu ważne czyli hierarchia wartości polskich i białoruskich studentów. Zeszyty Naukowe Politechniki Śląskiej. Seria: Organizacja i Zarzqdzanie, 123, 131-142.

KAŁUŻNY, R., KAŁUŻNY, Ł. (2014). Wartości uznawane przez studentów studiów niestacjonarnych. Edukacja Dorostych, 2, 175-189.

KAWCZYŃSKA-BUTRYM, Z. (2012). Rodzina jako wartość w badaniach młodzieży województwa warmińsko-mazurskiego. Forum Socjologiczne, 2, 277-296.

KitLiŃSKA-KRÓL, M. (2016). Preferencje aksjologiczne studentów pedagogiki. Chowanna, 1(46), 153-174.

KobYŁeCKA, E. (2009). Nauczyciele i uczniowie gimnazjum wobec wyborów wartości. Między pewnościa a zwatpieniem. Zielona Góra: Oficyna Wydawnicza UZ.

MAJKOWSKI, W. (2008). Etos rodziny a postmodernistyczna filozofia. W: W. MusZYŃSKI, E. SIKORA (red.), Miłość, wierność i uczciwość na rozstajach współczesności. Ksztalty rodziny wspótczesnej (s. 26-27). Toruń: Wydawnictwo Adam Marszałek.

MALEWSKA, E. (2008). Praca - wartość czy konieczność. W: R. Gerlach (red.), Edukacja i praca. Konteksty - wyzwania - antynomie. Bydgoszcz: Wydawnictwo Uniwersytetu Kazimierza Wielkiego.

Przybysz-Zaremba, M., SiedlaczeK-Szwed, A. (2018). VAlues APPRECiated By CONTEMPORARY YOUTH - BASED ON RESEARCH CONDUCTED AMONG POLISH-LITHUANIAN YOUTH. 5th International Multidisciplinary Scientific Conference on Social Sciences and Arts SGEM. SGEM 2018 Conference Proceedings Vol. 5. Sciences \& Society Issue 3.4. Sofia: Published by STEF92 Technolofy Ltd. ISBN 978-619-7408-56-0; ISSN 2367-5659. DOI: 105593/sgemsocial2018/3.4.

Przybysz-Zaremba, M. (2011). Family in the Life of Polish Youth - what Value is it? Journal of Educational Review, 4, 4(December), 589-593.

PrZybysz-Zaremba, M. (2011a). Family as Value. The Model of a Family Moulded by Graduating Students. Journal of Pedagogy and Psychology, 4, 1, 73-81. DOI: 10.2478/v10195-011-0046-1.

STRÓZIK, T. (2014). System wartości a ocena jakości życia młodzieży akademickiej w świetle badań ankietowych studentów uczelni Poznania. Studia oeconomica posnaniensia, 2, 2 (263), 5-23.

SzAFranieC, K. (2011). Młodzi 2011. Warszawa: Kancelaria Prezesa Rady Ministrów.

MilersKi B., ŚlIWERSKI B. (red.). (2000). Pedagogika. Leksykon. Warszawa: PWN.

WiĘCKIEWICZ, B. (2016). Małżeństwo jako wartość i cel życiowy w opinii młodzieży akademickiej. Spoleczeństwo i Rodzina, 48(3), 112-128.

Wolny, B. (2008). Wartości życia człowieka w opinii studentów pedagogiki. W: J. KostKIEWICZ (red.), Aksjologia w ksztatceniu pedagogów. Kraków: Oficyna Wydawnicza „Impuls”.

ZIELIŃSKA, A. (1995). Dla uczniów i nauczycieli z miasta. Najważniejszych pięć wartości. Edukacja i Dialog, 4 (67); http://edukacjaidialog.pl/archiwum/1995.93/kwiecień.108/dla_uczniow_i_nau czycieli_z_miasta_najwzniejszych_piec_wartosci.365.html (dostęp: 08.10.2019). 


\title{
WARTOŚĆ RODZINY W OPINIACH STUDENTÓW PAŃSTWOWYCH UCZELNI WYŻSZYCH. ZARYS PROBLEMU
}

\begin{abstract}
Streszczenie
Rodzina była i jest ważnym środowiskiem w życiu ludzi w różnym wieku. W sposób szczególny utożsamiają się z nią dzieci, które w życiu dorosłym konstruują podobny model rodziny. Autorki podjęły się próby poszukiwania odpowiedzi na następujące pytania: „Jakie są opinie studentów na temat wartości rodziny?”; „Czym jest dla nich rodzina?”; „Jaki model rodziny dominuje w ich wypowiedziach?” oraz „Co studenci są gotowi zrobić/poświęcić dla własnej rodziny?”. W tym celu przeprowadziły badania wśród 80 studentów czterech państwowych uczelni wyższych. $\mathrm{Z}$ uzyskanego materiału wynika, że rodzina nadal zajmuje priorytetowe miejsce $\mathrm{w}$ hierarchii wartości studiujących młodych dorosłych, jest dla nich wartością „,ponadczasową”, która pomimo wielu przeobrażeń społeczno-gospodarczych mocno osadzona jest w życiu człowieka. Badani konstruują model rodziny, podobny do własnej rodziny biologicznej, oparty na związku małżeńskim oraz scementowany narodzinami dzieci i ich wychowywaniem.
\end{abstract}

Słowa kluczowe: rodzina; wartość; autorytet.

\section{THE VALUE OF THE FAMILY IN THE OPINIONS OF STATE UNIVERSITY STUDENTS. AN OUTLINE OF THE PROBLEM}

\section{S u m m a r y}

The family has been and still is an important asset in the lives of people of all ages. In a special way, children make themselves identified with it, so as to be able to construct a similar family model in their adulthood. The paper authors have attempted to seek answers to the following questions: "What are the family values in the opinions of the students?"; "What does a family mean for them?"; "What family model dominates in their statements?" And "What are students ready to do/sacrifice for their own family?". This is why they conducted a survey among 80 students of four state-owned universities. The obtained material shows that the family still occupies a priority place in the hierarchy of values of young adult students, remains a "timeless" value for them, all the time being firmly embedded in human life despite many oncoming socio-economic transformations. The researched subjects tend to construct a family model similar to their own biological family i.e., the model based on a marriage and cemented by the birth of children and their upbringing.

Key words: family; value; authority. 